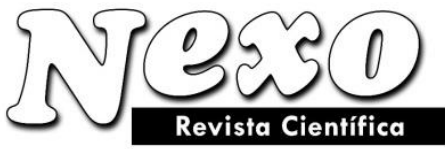

ISSN-E 1995-9516

Universidad Nacional de Ingeniería COPYRIGHT @ (UNI). TODOS LOS DERECHOS RESERVADOS

http://revistas.uni.edu.ni/index.php/Nexo

https://doi.org/10.5377/nexo.v33i02.10795

Vol. 33, No. 02, pp. 597-607/Diciembre 2020

(c) (i) (\$) $\Theta$

\title{
Competition as a Tool for Resource Allocation
}

\section{La competencia como herramienta para la asignación de recursos}

\author{
Milyausha Ildarovna Zakirova ${ }^{1}$, Elena Alexandrovna Rybkina ${ }^{1}$, Denis Sergeevich Balzamov ${ }^{2}$ \\ ${ }^{1}$ Kazan Federal University \\ ${ }^{2}$ Kazan State Power Engineering University \\ Corresponding author email: $\underline{\text { Rnd-project@mail.ru }}$
}

(recibido/received: 16-July-2020; aceptado/accepted: 19-September-2020)

\begin{abstract}
The article explores the definition of «competition» through an analysis of existing interpretations in the scientific literature. The authors reviewed and creatively revised more than 15 existing author's interpretations of this concept. The current approaches to the classification of competitions are systematized and creatively revised. On the example of a comparative table of classification approaches, the main classification features of competitions are revealed. The appropriateness of applying the concept of «competition» in children's, school and student competitions, as well as the concept of «open competition» used in the procurement of goods, works, services to meet state and municipal needs, is considered. As a result, the revealed signs of the competition allow us to conclude the appropriateness of using this concept as a tool for the distribution of material goods. In this case, they differ only in the scale of this distribution. The article also explores the list of olympiads and other intellectual and (or) creative contests, events aimed at developing intellectual and creative abilities, abilities to engage in physical education and sports, interest in scientific (research), engineering, inventive, creative, physical culture and sports activities, as well as the promotion of scientific knowledge, creative and sports achievements, recommended by the Ministry of Education of the Russian Federation. As a result, the target audience of participants for whom contests are initiated has been identified.
\end{abstract}

Keywords: competition, distribution of finance, competitive financing, classification of competitions, interdisciplinary competitions, educational and creative activity

\section{RESUMEN}

El artículo explora la definición de «competencia» a través de un análisis de las interpretaciones existentes en la literatura científica. Los autores revisaron y revisaron creativamente más de 15 interpretaciones de autores existentes de este concepto. Los enfoques actuales para la clasificación de las competiciones se sistematizan y revisan creativamente. En el ejemplo de una tabla comparativa de enfoques de clasificación, se revelan las principales características de 
clasificación de las competiciones. Se considera la conveniencia de aplicar el concepto de «competencia» en concursos infantiles, escolares y estudiantiles, así como el concepto de «competencia abierta» utilizado en la adquisición de bienes, obras, servicios para satisfacer las necesidades estatales y municipales. Como resultado, los signos revelados de la competencia nos permiten concluir la conveniencia de utilizar este concepto como herramienta para la distribución de bienes materiales. En este caso, difieren solo en la escala de esta distribución. El artículo también explora la lista de olimpiadas y otros concursos intelectuales y (o) creativos, eventos dirigidos al desarrollo de habilidades intelectuales y creativas, habilidades para participar en la educación física y el deporte, interés en la ciencia (investigación), ingeniería, inventiva, creativa, física. actividades culturales y deportivas, así como la promoción del conocimiento científico, los logros creativos y deportivos, recomendados por el Ministerio de Educación de la Federación de Rusia. Como resultado, se ha identificado el público objetivo de los participantes para los que se inician los concursos.

Palabras clave: competencia, distribución de financiamiento, financiamiento competitivo, clasificación de concursos, concursos interdisciplinarios, actividad educativa y creativa

\section{INTRODUCTION}

If earlier the word competition was more of a cultural and entertainment nature and was applied mainly to creative competitions, then in the last decade, competitions have tightly entered the financial distribution system.

So, the distribution of finances in the field of procurement of goods, work, services to meet state and municipal needs occurs through public competition (tender) and auctions. At the same time, public competition (tender) means a competition, in which the information on the purchase is communicated by the customer to an general public by posting in a single information system a notification about the holding of such a competition, tender documentation and uniform requirements are made to the participants in the purchase (Federal Law dated 05.04.2013 N 44Ф3).

In the education system, financing of state educational institutions takes place according to the normative per capita principle, taking into account the increasing coefficients that are assigned to each organization depending on the rank in the general list. This is a kind of competition among educational organizations during the academic year for the right to increased state financing. At the same time, personnel motivation systems of the same educational organizations are also being built on a competitive basis. The implementation of certain works allows you to take a place in the ranking and get the appropriate reward. Grants and subsidies for the implementation of youth, social, scientific, high-tech projects are distributed on a competitive basis through grant-forming organizations (funds). Competitions are also traditionally held for students in schools and universities in the following areas: culture and art, social activities, education and science, and sports. It turns out that the topic of competitive activity covers a lot of areas and target audiences. Therefore, the study of the concept of «competition» is of interest, and even more so the study of approaches to the classification of competitions.

\section{METHODS}

The basis of the study of the essence of the concept of "competition" is used such theoretical research methods as the search and subsequent analysis of existing interpretations in the scientific literature and the creative processing of the information received. 
The study of the competition classification system is based on a comparative analysis of the following approaches:

a. Popova V.I. and Kelsina A.S., set forth in the scientific work «Olympics in the system of search and development of gifted children» (Popova \& Kel'sina, 2011);

b. Belchusova AA, described in the work «Concept and typology of distance contests» (Bel'chusov, 2011);

c. Competitive selection of shift participants at the Artek International Children's Center (https://artek.org), the All-Russian Ocean Center for Children (https://okean.org), the Orlenok All-Russian Children's Center (https://center-orlyonok.ru);

d. Open tenders in the field of procurement of goods, works, services to meet state and municipal needs (Federal Law dated 05.04.2013 N 44-Ф3) by the example of $\mathrm{T}$. Yusupova's approach in the work «Tendering: management audit issues» (Yusupova, 2010);

e. Competitive selection of the best projects in the field of -fundamental, exploratory and applied research carried out by the Foundation for Assistance to Small Innovative Enterprises (Yusupova, 2010), the Presidential Grants Development Fund for the Development of Civil Society (The official website of the Foundation for Assistance to Small Innovative Enterprises), and the Russian Foundation for Basic Research (https://президентскиегранты.pф), The Russian Science Foundation (https://www.rfbr.ru).

\section{RESULTS AND DISCUSSION}

To clarify the interpretation of the term «competition», it is proposed to turn to explanatory dictionaries. At the same time, it can be noted that most of the authors of the interpretations define this concept as a kind of competition:

a. with the goal of highlighting the best participants, the best work (The official website of The Russian Science Foundation);

b. to identify the best of the participants of the submitted works (Ozhegov, 1949);

c. in order to identify from the list of the most worthy participants or the best works (Bol'shoj enciklopedicheskij slovar', 2003);

d. giving the opportunity to identify the most worthy of its participants (Efremova, 2006);

e. on which the strongest participants are determined and awarded (Evgen'eva, 1999);

f. the competition of several persons in the field of art, sciences, sports in order to highlight the most prominent (Dmitriev, 2003). Note that D. N. Ushakov supplemented his definition with specific areas of activity where competitions can be held.

The concept of «competition» in the Big Dictionary of the Russian Language is interpreted as a review of someone, something that makes it possible to identify the most worthy of its participants (Ushakov, 1935-1940). In other words, this is a public display, familiarization with the material provided, on the basis of which the best can be determined.

The Explanatory Dictionary of the Living Great Russian Language by V. Dal' (Kuznecov, 1998) interprets the competition as a competition for an award, a place, a title; competition lawsuit, competition. Those. in this definition, the emphasis is on the fact that competition is a way to receive remuneration for the work performed. It reflects the motive for participating in competitions.

The term «competition» is more fully disclosed as a form of organization of an activity or process:

a. the form of organization of extracurricular activities of students (Dal', 1863-1866); 
b. a special form of organization of such educational activities, which is aimed at identifying the best participants and which can be carried out both during the lesson and in extracurricular activities (any competitions, games, tournaments, competitions, conferences, festivals, etc.) (Kirilova \& Volik);

c. a form of organization of the pedagogical process, stimulating the activity of the individual, where the creative abilities of schoolchildren, cognitive activities are updated, the abilities and interests of students are realized (Kuznecova \& Melekesova, 2012);

d. a form of organization of the educational process, during which the identification and development of creative abilities, self-determination, and the implementation in the competitive activity of their desire for socially significant achievements are carried out (Ksenofontova \& Tabakova, 2006).

Also, the competition is considered as a tender, that is, a competitive form for the selection of proposals for the supply of goods, the provision of services or the performance of work according to conditions previously announced in the documentation, on time, on the principles of competitiveness, fairness and effectiveness (Gilyadov, 2015; Fridlyanov, 2010; Smirnov \& Ershova, 2014; Laryea, 2011).

Having considered the presented interpretations, we highlight the main features of the competition:

a. vigorous activity and social activity;

b. competitiveness;

c. fairness;

d. effectiveness and efficiency.

Analyzing the interpretation of the term «competition» (Federal Law dated 05.04.2013 N 44-Ф3; Popova \& Kel'sina, 2011; Bel'chusov, 2011; The official website of The Russian Science Foundation; Ozhegov, 1949; Bol'shoj enciklopedicheskij slovar', 2003; Efremova, 2006; Evgen'eva, 1999; Dmitriev, 2003; Ushakov, 1935-1940; Kuznecov, 1998; Dal', 1863-1866; Kirilova \& Volik; Kuznecova \& Melekesova, 2012; Ksenofontova \& Tabakova, 2006; Gilyadov, 2015; Fridlyanov, 2010; Smirnov \& Ershova, 2014; Laryea, 2011; Zagvyazinskij, 2008), we can conclude:

a. a competition is such a form of organization of an activity or a process as competition, competition for an award that provides an opportunity to determine the best of the participants and realize their desires and skills;

b. there is a need for classification of competitions.

After analyzing the literature, it was not possible to find a complete classification system for competitions. However, several basic approaches to the classification of competitions were identified (see «Methods»). It should be noted that a small number of works (Dal', 1863-1866; Kirilova \& Volik; Kuznecova \& Melekesova, 2012), in which there are attempts to classify competitions, are also identified. However, the classification presented in these works is not complete. Based on this, an attempt is made to summarize the accumulated material in the format of comparative table 1, including: the approach of Popova V.I. and Kelsina A.S.; Belchusova A.A.; the approach used to select shift participants at the International Children's Center «Artek», the Russian Children's Center «Okean» and Russian Children's Center the «Orlenok»; and approach to evaluating tenders as tenders O.A. Yusupova. 
Table 1: Comparison table of approaches to the classification of competitions

\begin{tabular}{|c|c|c|c|c|c|c|}
\hline Classification feature & $\begin{array}{c}\text { Popova V.I., } \\
\text { Kelsina A.S. } \\
{[2]}\end{array}$ & $\begin{array}{c}\text { Belchusova } \\
\text { A.A. [3] }\end{array}$ & $\begin{array}{c}\text { «Artek» } \\
{[4]}\end{array}$ & $\begin{array}{c}\text { «Okean» } \\
{[5]}\end{array}$ & $\begin{array}{c}\text { «Orlenok» } \\
{[6]}\end{array}$ & $\begin{array}{c}\text { Yusupova } \\
\text { O.A. [7] }\end{array}$ \\
\hline \multicolumn{7}{|l|}{ Level } \\
\hline School & $\checkmark$ & & & & & \\
\hline urban & $\checkmark$ & & $\checkmark$ & & & \\
\hline district & $\checkmark$ & & $\checkmark$ & & $\checkmark$ & \\
\hline regional & $\checkmark$ & & $\checkmark$ & & $\checkmark$ & \\
\hline zonal & $\checkmark$ & & $\checkmark$ & & & \\
\hline All-Russian & $\checkmark$ & & $\checkmark$ & & $\checkmark$ & \\
\hline interregional & & & $\checkmark$ & & & \\
\hline international & $\checkmark$ & & $\checkmark$ & & $\checkmark$ & \\
\hline \multicolumn{7}{|l|}{ Form } \\
\hline absentee & $\checkmark$ & & $\checkmark$ & & & \\
\hline full-time & $\checkmark$ & & $\checkmark$ & & & \\
\hline extramural & $\checkmark$ & & & & & \\
\hline network & $\checkmark$ & & & & & \\
\hline \multicolumn{7}{|l|}{ Number of participants } \\
\hline team & $\checkmark$ & & & & & \\
\hline personal (individual) & $\checkmark$ & & & & & \\
\hline \multicolumn{7}{|c|}{ Admissibility of Competition Requirements } \\
\hline one-stage & & & $\checkmark$ & & $\checkmark$ & $\checkmark$ \\
\hline two-stage & & & $\checkmark$ & & $\checkmark$ & $\checkmark$ \\
\hline \multicolumn{7}{|l|}{ list of participants } \\
\hline open & & & & & & $\checkmark$ \\
\hline closed & & & & & & $\checkmark$ \\
\hline \multicolumn{7}{|l|}{ Subject of organization } \\
\hline $\begin{array}{l}\text { depends on the organizer: } \\
\text { school, college, university }\end{array}$ & $\checkmark$ & & & & & \\
\hline \multicolumn{7}{|l|}{ Content } \\
\hline sport & & $\checkmark$ & & $\checkmark$ & $\checkmark$ & \\
\hline
\end{tabular}




\begin{tabular}{|l|l|c|c|c|c|c|}
\hline education and science & & $\checkmark$ & & $\checkmark$ & $\checkmark$ & \\
\hline culture and art & & & & $\checkmark$ & $\checkmark$ & \\
\hline social work & & & & $\checkmark$ & $\checkmark$ & \\
\hline tourist and regional studies & & & & & $\checkmark$ & \\
\hline
\end{tabular}

Based on the data in Table 1, it can be concluded that tenders can be classified according to the following main criteria:
a. level of conduct;
b. form of carrying out;
c. number of participants;
d. on the subject of the organization;
e. in content.

At the same time, some approaches to classification provide for splitting the sign «content of the competition» (table 2).

Table 2: Detailing of the classification attribute «Content»

\begin{tabular}{|c|c|c|c|}
\hline Classification feature & Belchusova A.A. [3] & «Okean» [5] & «Orlenok» [6] \\
\hline \multicolumn{4}{|c|}{ Sport } \\
\hline martial Arts & & $\checkmark$ & $\checkmark$ \\
\hline applied & & $\checkmark$ & \\
\hline military applied & & $\checkmark$ & \\
\hline complicated & & $\checkmark$ & \\
\hline cyclic & & $\checkmark$ & \\
\hline gaming & $\checkmark$ & $\checkmark$ & \\
\hline marathon & $\checkmark$ & & \\
\hline match & $\checkmark$ & & \\
\hline championship & $\checkmark$ & & \\
\hline sports day & $\checkmark$ & & \\
\hline tournament & $\checkmark$ & & \\
\hline champion & $\checkmark$ & & \\
\hline relay race & $\checkmark$ & & \\
\hline \multicolumn{4}{|c|}{ Education and science } \\
\hline research & & $\checkmark$ & $\checkmark$ \\
\hline project work & & $\checkmark$ & \\
\hline
\end{tabular}




\begin{tabular}{|c|c|c|c|}
\hline subject Olympiads & $\checkmark$ & $\checkmark$ & $\checkmark$ \\
\hline inventive work & & $\checkmark$ & \\
\hline other festivals / competitions & $\checkmark$ & $\checkmark$ & $\checkmark$ \\
\hline \multicolumn{4}{|c|}{ Culture and art } \\
\hline arts and crafts & & $\checkmark$ & \\
\hline literary & & $\checkmark$ & \\
\hline folk art & & $\checkmark$ & \\
\hline technical & & $\checkmark$ & $\checkmark$ \\
\hline performing arts & & $\checkmark$ & \\
\hline artistic & & $\checkmark$ & $\checkmark$ \\
\hline \multicolumn{4}{|c|}{ Social work } \\
\hline ecology, healthy lifestyle & & $\checkmark$ & \\
\hline diplomacy / Language Olympiads & & $\checkmark$ & \\
\hline volunteering & & $\checkmark$ & \\
\hline leadership & & $\checkmark$ & \\
\hline search, military-patriotic & & $\checkmark$ & \\
\hline media & & $\checkmark$ & \\
\hline Tourist and regional studies & & & $\checkmark$ \\
\hline
\end{tabular}

\section{SUMMARY}

Therefore, it is recommended that competitions be classified by:

a. Level of conduct at: school, district, regional, all-Russian, international;

b. The form of conducting: absentee, full-time.

The most important criterion for the classification of competitions that attracts the attention of potential participants is the direction of the competition, that is, determining the type of competition in content (table 2). It is recommended to highlight the following areas:
a. Sport;
b. Education and science;
c. culture and art;
d. Social work.

The proposed classification has been tested on the example of competitions included in the list of olympiads and other intellectual and (or) creative competitions recommended by the Ministry of Education of the Russian Federation, events aimed at developing intellectual and creative abilities, abilities for physical education and sports, interest in scientific (scientific and research), engineering, inventive, creative, physical-sports activities, as well as the promotion of scientific knowledge, creative and sports achievements (Order of the Ministry of Education of Russia). We 
have reviewed 222 provisions for contests and events from this list. Table 3 shows the distribution by direction.

Table 3: Competition structure by directions

\begin{tabular}{|l|l|}
\hline \multicolumn{1}{|c|}{ Name of direction } & \multicolumn{1}{c|}{ Quantity, pcs. } \\
\hline Sport & 8 \\
\hline Education and science & 160 \\
\hline Culture and art & 47 \\
\hline Social work & 7 \\
\hline Total & $\mathbf{2 2 2}$ \\
\hline
\end{tabular}

*Source: compiled by the authors on the basis of the article (Order of the Ministry of Education of Russia).

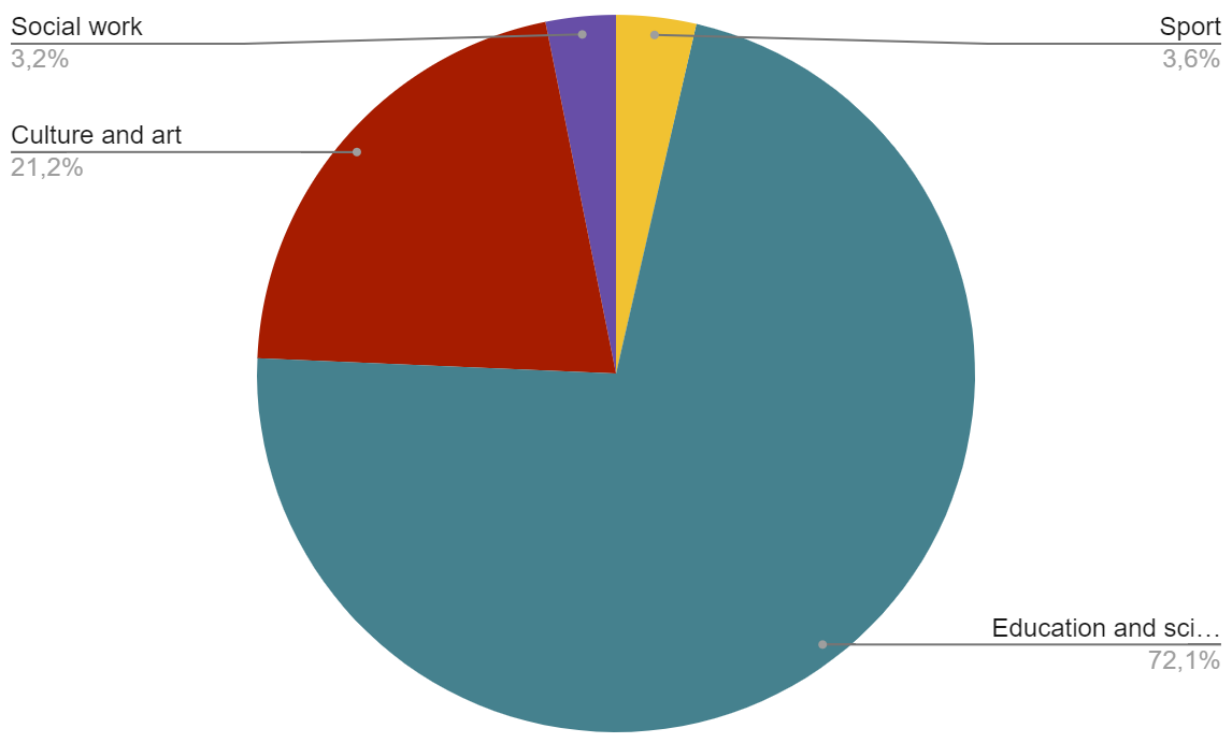

Figure 1: Distribution of competitions, \%

Thus, as a result of the study, it became clear that most $(72 \%)$ of competitions and events recommended by the Ministry of Education of the Russian Federation are held in the direction of «Education and Science»; the smallest percentage (3\%) - in the direction of «Social activity».

In our approaches to the classification of competitions, there was no such classification criterion as «age of participants». However, using the example of the list of competitions recommended by the Ministry of Education and Education of the Russian Federation, the age limit of potential participants in the competitions is studied. Summary results are presented in table 3.

Table 3: Data Pivot Table

\begin{tabular}{|l|c|c|}
\hline Category (Vozrast, 1991) & Age, years & Quantity, people (Vozrast, 1991) \\
\hline Primary school age & $6-12$ & 75 \\
\hline
\end{tabular}




\begin{tabular}{|l|c|c|}
\hline Teenage years & $12-17$ & 200 \\
\hline Youthful period & $17-21$ & 83 \\
\hline Mature age, 1 period & $21-35$ & 28 \\
\hline Mature age, 2 period & $35-60$ & 4 \\
\hline
\end{tabular}

* Source: compiled by the authors on the basis of the article (Order of the Ministry of Education of Russia).

In the formation of table 3, age-related periodization was used, based on anatomical, physiological, and socio-psychological characteristics (Vozrast, 1991-1996; Rodin, 2018; Andreeva, 2019).

The distribution of contestants by age is graphically presented in the form of a diagram in Figure 2.

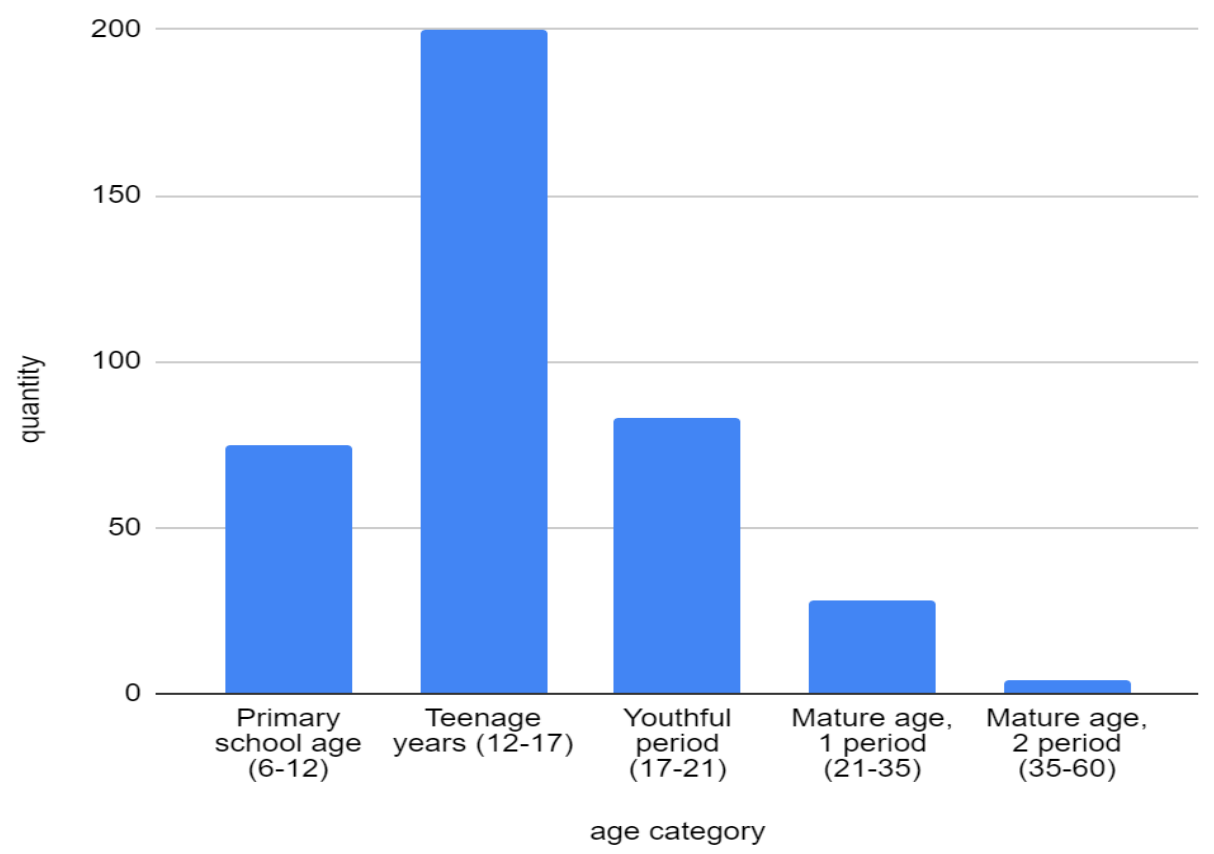

Figure 2: Distribution of contestants by age

Figure 2 clearly demonstrates that activities to a large extent (90\%) are designed for adolescent students. In matters of participation in grant competitions from individuals, the issue of age restrictions is also important.

However, in matters of holding open tenders as tenders (state and municipal procurements), the age limit does not matter. It becomes important organizational and legal form of organization - a bidder.

\section{CONCLUSIONS}

Competitions cover almost all areas of knowledge and capture participants in all sectors of the economy. The main features of competitions are: 
a. vigorous activity and social activity. This involves proactive participation.

b. competitiveness, competitiveness, which is aimed at improving the quality of the material / proposal submitted to the competition.

c. justice. This characteristic expands the boundaries and equalizes the chances of all potential participants.

d. effectiveness and efficiency directly determine the motive for the active activity of potential participants.

As classification signs, it is recommended to allocate to the level of conduct; according to the form of holding; content (direction); type of participant (individual, legal entity). At the same time, it is proposed to divide the directions into: sports, education and science, culture and art, social activities.

\section{ACKNOWLEDGEMENTS}

\section{The work is performed according to the Russian Government Program of Competitive Growth of Kazan Federal University.}

\section{REFERENCES}

Andreeva, A.D. (2019). Psychological features of adults' perception of modern childhood duration. Science and society, 3, 37-47.

Bel'chusov, A.A. (2011). Ponyatie i tipologiya distancionnyh konkursov [The concept and typology of distance contests]. Vestnik Chuvashskogo gosudarstvennogo pedagogicheskogo universiteta im. I.YA. Yakovleva, 3-1(71), 27-37. (in Russian)

Bogoyavlenskaya, D.B. (2002). Psihologiya tvorcheskih sposobnostej [Psychology of creative abilities]. M.: Akademiya, 224. (in Russian)

Bol'shoj enciklopedicheskij slovar' (2003). [Great Encyclopedic Dictionary], M.: AST: Astrel'. (in Russian)

Dal', V.I. (1863-1866). Tolkovyj slovar' zhivogo velikorusskogo yazyka [Explanatory Dictionary of the Living Great Russian Language], 4 T., St. Petersburg. (in Russian)

Dmitriev, D.V. (2003). Tolkovyj slovar' russkogo yazyka Dmitrieva [Explanatory dictionary of the Russian language Dmitrieva]. (in Russian)

Efremova, T.F. (2006). Sovremennyj tolkovyj slovar' russkogo yazyka [The modern explanatory dictionary of the Russian language]: In 3 vols. M.: AST: Astrel', Harvest. (in Russian)

Evgen'eva, A. P. (1999). Slovar' russkogo yazyka [Dictionary of the Russian language]: V 4 t. RAN, In-t lingvistich. issledovanij; Pod red. A.P. Evgen'evoj. M.: Russkij yazyk; Poligrafresursy. (in Russian)

Federal Law dated 05.04.2013 N 44-Ф3 (as amended on 06/08/2020) «On the contract system in the field of procurement of goods, work, services to meet state and municipal needs» [O kontraktnoj sisteme v sfere zakupok tovarov, rabot, uslug dlya obespecheniya gosudarstvennyh i municipal'nyh nuzhd] (as amended and supplemented, entered into force 07/01/2020). (in Russian)

Fridlyanov, V. (2010). Nauchnaya ekspertiza vmesto tendera na gumanitarnye znaniya [Scientific expertise instead of a tender for humanitarian knowledge]. Obshchestvo i ekonomika, 12, 112-120. (in Russian)

Gilyadov, S.R. (2015). Konkurs i konkursnaya (sorevnovatel'naya) deyatel'nost' shkol'nikov [Competition and competitive (competitive) activity of schoolchildren], Nacional'naya associaciya uchenyh, 88-90. (in Russian)

Kirilova, G.I., \& Volik, O.N. Proektirovanie i realizaciya konkursa komp'yuternogo tvorchestva [Design and implementation of a computer art contest - access mode]. URL: http://www.den-za-dnem.ru/page.php? article $=165$. (in Russian)

Ksenofontova, A.N., \& Tabakova, E.P. (2006). Pedagogicheskie usloviya samoopredeleniya starsheklassnikov v konkursnoj deyatel'nosti [Pedagogical conditions of self-determination of high school students in competitive activity]. Vestnik Orenburgskogo gosudarstvennogo universiteta, 10(1), 88-94. (in Russian)

Kuznecov, S.A. (1998). Bol'shoj tolkovyj slovar' russkogo yazyka [Large explanatory dictionary of the Russian language]. $1 \mathrm{Ed}, \mathrm{SPb} .:$ Norint. (in Russian) 
Kuznecova, O.V., \& Melekesova, R.M. (2012). K voprosu o konkursnoj deyatel'nosti uchashchihsya [To the question of students' competitive activity]. Internet-journal «Naukovedenie», 4 (13). (in Russian)

Laryea, S. (2011). Quality of tender documents: case studies from the UK. Construction Management \& Economics, 29(3), 275-286.

Moskvina, A.V., \& Kochemasova, L.A. (2019). Competition of research and creative works as a form of students' self-realization [Konkurs nauchno-issledovatel'skih i tvorcheskih rabot kak forma samorealizacii studentov], Vestnik samarskogo gosudarstvennogo tekhnicheskogo universiteta. Seriya: psihologopedagogicheskie nauki [Bulletin of Samara State Technical University. Series: psychological and pedagogical sciences], 2, 119-133. (in Russian)

Order of the Ministry of Education of Russia «On approval of the list of Olympiads and other intellectual and (or) creative contests, events aimed at developing intellectual and creative abilities, abilities for physical education and sports, interest in scientific (research), engineering, inventive, creative, athletic and sports activities, as well as the promotion of scientific knowledge, creative and sports achievements, for the 2019/20 academic year» dated July 24, 2019 No. 390 // as amended. Order of the Ministry of Education of Russia of 12.27.2019 N 737. (in Russian)

Ozhegov, S. I. (1949). Slovar' russkogo yazyka [Dictionary of the Russian language]. M.,. (in Russian)

Popova, V.I., \& Kel'sina, A.S. (2011). Olimpiady v sisteme poiska i razvitiya odarennyh detej [Olympiads in the system of search and development of gifted children]. Problemy razvitiya territorii, 3(55), 84-93. (in Russian)

Rodin, A.V. (2018). Age periodization of individual tactical training of athletes in game sports. Osnovnye problemy fizicheskogo vospitaniya i sportivnoj podgotovki, 485-488.

Smirnov, E.B., \& Ershova, S.A. (2014). Development of construction cost assessment methods during preparation for tender. Advanced materials research, 1020, 854-858.

The official website of Russian Foundation for Basic Research. URL:https://www.rfbr.ru.

The official website of the Foundation for Assistance to Small Innovative Enterprises. URL: http://fasie.ru.

The official website of the FSBEI «All-Russian Children's Center «Ocean». URL: https://okean.org

The official website of the FSBEI «All-Russian Children's Center «Orlenok». URL: https://center-orlyonok.ru

The official website of the FSBEI «International Children's Center «Artek». URL: https://artek.org.

The official website of the Presidential Grants Development Fund for the Development of Civil Society. URL: https://президентскиегранты.pф.

The official website of The Russian Science Foundation. URL: https://rscf.ru.

Ushakov, D.N. (1935-1940). Tolkovyj slovar' russkogo yazyka [Explanatory dictionary of the Russian language]: V 4 t. / Pod red. D. N. Ushakova. M.: Sov. encikl.: OGIZ,. (in Russian)

Vozrast [Age], Malaya medicinskaya enciklopediya [Small Medical Encyclopedia], M.: Medicinskaya enciklopediya. 1991-1996. (in Russian)

Yusupova, O.A. (2010). Tendering: management audit, Vestnik Omskogo universiteta. Seriya «Ekonomika», 3, 189195. (in Russian)

Zagvyazinskij, V.I. (2008). Pedagogicheskij slovar': ucheb. posobie dlya stud. vyssh. ucheb. Zavedenij [Pedagogical dictionary: textbook. allowance for students. higher textbook. institutions] / V.I. Zagvyazinskij, A.F. Zakirova, T.A. Strokova.; pod red. V.I. Zagvyazinskogo, A.F. Zakirovoj. M.: Akademiya, 352. (in Russian)

Zakirova M. I., born October 13, 1998. Student 3th year of Institute of Physics of Kazan (Volga region) Federal University. A native of the city of Shemordan. Studying in the direction of «Innovation».

Rybkina E.A. is a practitioner in the field of project management. She was the author and supervisor of the master's program "Project Management" at Kazan State Energy University. He has been involved in project financing for more than 15 years.

Balzamov D.S. is an Associate Professor Department of Energy supply of enterprises and energy-saving technologies, Kazan State Power Engineering University. The scientific direction is the field of high-tech projects in the energy industry. 